\title{
海 藻多糖体
}

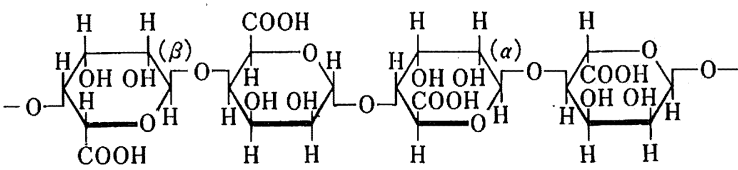

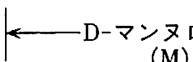

(M)

(G)

海洋に棲息する海藻は緑藻，紅藻，褐藻の三藻門に 分類され, 光合成による炭酸固定と海中の養分を藻体 全体から吸収し，成長している。 天日や波浪にさらさ れる潮間帯や潮通しの速い場所でも藻体は見事に水分 を保ちまた柔軟性をもってしなやかな動きをみせて, 自然の厳しい環境を住み分け合いながら繁茂してい る. 筆者はコンブ綱の流水抵抗の測定に際してコンブ が中肋を背にして葉状帯をひらひらさせて流速を避け る様子に感心した経験がある.さてこの生態環境にも 寄因する海藻の生体成分の特色は, 陸上植物と比べて 一般に水分量が高く，糖質を主成分として低分子から 高分子物質まで多種類でしかも粘質多糖体（ゲル状物 質）をもち，さらに多種のミネラルを保持しているこ とである. 特に多糖体は海藻の種類で特徴があり, 化 学的性質も異なる。ここでは海藻の多糖体全般につい ては既刊の著書にゆずり, 天然高分子資源として海藻 の多糖について述べる。

海藻の細胞壁の成分は一般には微細で結晶度の低い セルロースを主とするが, 紅藻, 緑藻, にはマンナン やキシランのようなへミセルロースを成分とするもの もある. 藻体内の細胞間隙は, 海藻種で特色をもつ粘 質多糖体で占められている，紅藻ではアガール（寒天 質）(テングサ，オゴノリ）やカラゲナン（キリンサ イ, ツノマタ), フノラン(フノリ) およびポルフィ ラン（ノリ）である。褐藻にはアルギン酸やフコイダ ン (コンブ, アラメ, ホンダワラ) がある。この粘質 多糖は種属により化学構造は異なるものが多いが, 海 藻成分中特筆する物質であり, また海藻工業に広く利 用されている。

a) 寒天：ガラクタン誘導体から成る紅藻特有の多糖 体でトコロテンとして一番馴じみがあろう。冷水には 難溶でゲルを作る性質があり菓子類, 缶詰など食品に また微生物の培地として利用されている. 生産量は年 産 6 千 $\mathrm{t}$ のうち日本で約半分が製造されている。

b ）カラゲナン：硫酸エステル基を一部含む酸性ガラ クタン誘導体である。水溶液は粘稠で通常では固まら

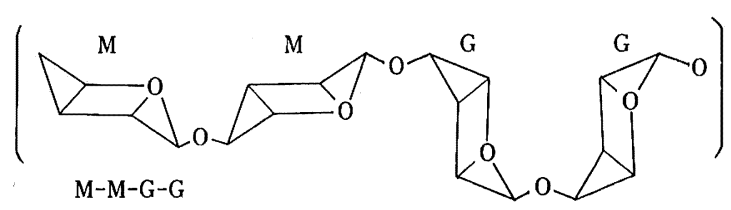

アルギン酸の化学構造

ないが, $\mathrm{K}^{+} や \mathrm{NH}_{4}^{+}$の存在でゲル化し，またタンパ クとも良く結合してゼリー状になるもの $(\varkappa)$ や無機 イオン, タンパク質とも固まらず親水性の高い $(\lambda)$ などがあり，ミルクやペーストなど食品分野で用途が 高い。このような物性の違いは構成糖と硫酸含量によ る. 以上は紅藻の代表的粘質多糖である.

c) アルギン酸：褐澡類に $14 \sim 40 \%$ 含有する粘質多 糖で $\mathrm{Na}$ 塩は溶解性も良く滑らかで粘稠な液となる. しかし $\mathrm{Ca}^{++}, \mathrm{Sr}^{++}, \mathrm{Al}^{++}$など多価イオンとは強く結合 してゲル化する．ゲルは寒天に比べ柔らかく，加熱に も強い特長がある.アルギン酸の抽出は褐澡の種類や 調整工程により各種の粘度が得られ，天然高分子を扱 うため分解制御という化学合成とは違った技術面があ る。用途は増粘剤, 乳化安定剤, 食品添加剤や繊維用 糊料とくに捺染剤など幅広い。さらにバイオリアクタ 用包括担体ゲル，バイオペーパーおよび抗ウィルス， 抗腫喳の薬効作用による医薬品, 葉面散布農薬剤への 新しい需要も期待される.

さてアルギン酸の化学構造（図）はマンヌロン酸 (M) とグルロン酸 $(\mathrm{G})$ の 2 種からなり組成はMのみ の平らなリボン状ポリマー $(\overline{\mathrm{DP}} \div 10)$ と凹みのある 折れ曲り構造をもつ $\mathrm{G} ホ ゚ リ マ ー ~(\overline{\mathrm{DP}} \doteqdot 15)$ および $\mathrm{MG}$ のブロック $(\overline{\mathrm{DP}} \div 20)$ からなるへテロポリマーであ る.この $\mathrm{M}, \mathrm{G}$ 構成比 $(\mathrm{M} / \mathrm{G}=0.6 \sim 2.4)$ と分子の鎖 長は海藻の種類や藻体部位および成長期により異な り，また当然物性にも影響する。例えば $\mathrm{G}$ ポリマーは $\mathrm{Ca}^{++}$と強固に結合して網目構造をとり,ゲルの堅さ や熱安定性を増加させる。

現在，われわ机は北海道伊達市における「コンブの 大量生産と有価物製造」のプロジェクトに携わってい る.コンブの糖質はマンニット, アルギン酸, 粗繊 維, ラミナラン, フコイダンがある. フコイダンはフ コースをもつ水溶性硫酸多糖体で血液凝固防止や高脂 血清净作用などで注目されている。

本谷 益良 Masura Honya (石川島播磨重工業(株) 技術研究所 - 主任，専門=生物化学) 